\title{
The Film and Audiovisual Production in Montreal: Challenges of Relational Proximity for the Development of a Creative Cluster
}

\author{
DIANE-GABRIELLE TREMBLAY \\ ELISA CECILLI
}

\begin{abstract}
Film and audiovisual production are part of the new media sector, one of the main sectors of the creative industries. The sector has evolved from purely audiovisual techniques to various creative specialized services used in television, advertising, and motion pictures. Montreal has long been known as an important North American hub for film and audiovisual production. This reputation has continued over recent years with important developments in the visual effects sector. However, increased competition over recent years and the desire to maintain activity in Montreal have spurred interest for the application of a cluster policy in the film and audiovisual sector, and interest in relational proximity has increased in order to ensure this creative industry's future. We investigated the birth of the cluster policy in this sector and this article
\end{abstract}

Diane-Gabrielle Tremblay is Canada Research Chair on the Socio-organizational challenges of the Knowledge Economy and professor in Economics and Management at the Télé-université of the Université du Québec à Montréal (UQAM). She is also director of the Community-University Research Alliance on Work-Life Balance over the Lifecourse, and president of the Sociology of Work Research Committee of the International Sociological Association. Elisa Cecilli was research assistant at the Canada Research Chair on the Socio-organizational challenges of the Knowledge Economy of the Téléuniversité of the Université du Québec à Montréal (UQAM) in 2007-2009; she has a Masters in Arts and Culture management from the Trentino School of Management, Rovereto, Italy and a BA in Economics from the University of Rome. Copyright (C) 2009 Heldref Publications 
discusses the challenges and difficulties in developing cooperation between businesses of a competitive creative sector, highlighting the fact that geographic or physical proximity is not enough and that relational proximity is not so easy to develop. It also highlights sources of success and thus can be useful for a better understanding of proximity issues in relation to creative cluster development.

\section{INTRODUCTION}

$\mathrm{F}$ ilm and audiovisual production have been evolving over recent years and are now often seen as part of the new media sector, one of the main sectors of the creative industries sectors. The sector has evolved from purely audiovisual techniques to various creative services used in television, advertising, and film. Montreal has long been known as an important North American hub for film and audiovisual production, especially with the presence of the French and English production of the Canadian Broadcasting Corporation (CBC) and the National Film Board of Canada (NFB). This reputation has continued over recent years with important developments in visual effects, often related as well to the important developments in the multimedia sector and the Multimedia City of Montreal, which has attracted important firms such as Ubisoft and Electronic Arts. However, the protectionist attitude of the Hollywood filmmakers at times, as well as the negative effects of the long screenwriters' strike in Hollywood on Montreal production, have been amongst the factors that have spurred important preoccupations for the future of Montreal film and audiovisual production. In this context, the City of Montreal has decided to develop a cluster strategy to protect and develop the future of this creative industry in Montreal, in the context of increased competition in the sector from the United States and other Canadian provinces. It is in this context that efforts have been made since 2004 to try to develop a cluster strategy in this sector and ensure this creative industry's future. The birth and development of the multimedia cluster in Montreal as well as Vancouver and Toronto has been well documented (Britton et al. 2009), so we wanted to look into the development of another creative sector not as strongly supported by the provincial government ${ }^{1}$; we chose the film and audiovisual production cluster to investigate the birth of a creative cluster and identify its challenges and difficulties, as well as the sources of success for the development of a creative cluster.

Our article will thus highlight the challenges and difficulties in developing cooperation between businesses of a very competitive creative sector, something that seems important to us since writings on clusters too often present fully mature clusters, without showing the difficulties and challenges often related to cluster creation and development of relational proximity, which could lead to more innovation and competitiveness. It thus appears useful to look into emerging clusters to identify these challenges related to proximity issues not 
only to have a more realistic picture of relational proximity and cluster development, but also to help governance bodies and firms in other sectors better understand the fact that cluster development is a lengthy process-maybe all the more so in sectors that are less concentrated and count more small and medium-sized businesses than large firms, and thus many more independent actors, making relational proximity more difficult to nurture. ${ }^{2}$

In this paper, we will begin by defining the concepts of clusters and proximity in more detail as they are often taken for granted, but we consider it important to present our view and highlight the recent debates on this concept. Once this is done, we will then define the cluster policy of the City of Montreal, especially as concerns the film and audiovisual production sectors, and, finally, we analyze the process of cluster development in this sector, highlighting difficulties and challenges encountered in the process of cluster creation. Our paper will thus center on the process of cluster creation, as well as on the conditions that appear to facilitate or to impede the development. For this, we will thus start by highlighting the theoretical views on these issues related to cluster creation.

\section{THEORETICAL FRAMEWORK: PROXIMITY AND CLUSTERS}

\section{Clusters}

Theories of regional specialization, agglomeration, and clustering have existed in some form for quite some time, over one hundred years if we go back to the Marshallian district (Marshall 1889). However, these theories seem to have been rediscovered in recent years. There has been much interest over the last two decades on behalf of researchers, but also from government and public policy analysts, in the search for modes of local regional development or reconversion of deindustrialized zones. Some consider that the cluster theory re-emergence is attributable to work undertaken by Porter (1990, 2003), while others attribute this re-emergence to interest in the industrial districts and in what have been termed innovative milieux in French and Swiss literature. As Cassidy et al. (2005) indicate, many governments and public policy organizations are very interested in the concept of clusters and many adopted it as a public policy instrument in order to increase local and regional (and eventually even national, in some cases), competitiveness, innovation, and growth (Organisation for Economic Co-operation and Development 1999, 2001).

Why this interest in clusters? It is largely because of the importance of innovation and creative capacity, which are seen as fundamental factors of economic development and prosperity in the knowledge economy. Over recent decades, theories of innovation systems and clusters have put forward the idea 
that the territorial dimension is important in shaping innovative and creative capacities (Gertler and Wolfe 2005).

As Cassidy et al. $(2005,5)$ also remind us, "the development of clusters promised a seemingly easy answer to the challenges created by increased international competition and the growing importance of innovation in the knowledge economy - particularly for smaller regions tied to traditional industries. Policy analysts, academics, and industry leaders were happy to follow as it simplified their task of explaining and promoting regional development economics. This enthusiasm was further fueled by the significant amounts of public money that flowed to cluster development initiatives." This surely explains much of the interest in clusters. However, despite the interest, there has been some criticism over the years.

For example, Martin and Sunley $(2003,7)$ are somewhat skeptical of the concept, commenting that "clusters have gate-crashed the economic policy arena" and that "the cluster concept should carry a public policy health warning." Cassidy et al. (2005) also indicate that a seminar held on government cluster intervention concluded that "ultimately, cluster initiatives have become a sort of 'magic recipe' to meet the challenges of the new economy, to the point that they have become dangerously fashionable" (Andersson et al. 2004, 10).

Beyond this criticism, and beyond the possibly overplayed public policy attraction, researchers have in our view highlighted elements of interest over recent years. Indeed, the concept remains useful, and it is important to go beyond the general definitions of clusters and highlight the elements that this strand of literature has contributed to highlight as sources of competitiveness and socioeconomic development.

Both clusters (single sector) and innovative milieux (multi-sector agglomerations) are geographical concentrations of firms and supporting organizations that "trust" one another and frequently exchange knowledge. The theory of innovative milieux emphasizes the role of the milieux as a source of innovation and industry growth: the proximity of competencies promotes the creation of new innovative firms (Camagni and Maillat 2006). This accent on competencies appears all the more important to us in the context of creative industries and, in our view, the development of competencies is one of the main sources of success for a cluster. Cassidy et al. state that

whether the cluster concept is useful, whether cluster development is possible, or whether government intervention is warranted, are matters for evaluation. The cluster concept is not being discredited, but faith is not enough. As with any investment, particularly involving public funds, there is a need for accurate and ongoing measures of success-evidence that the investment is having, or will have, net positive benefits. Unfortunately, there is a scarcity of comprehensive evaluations of clusters, and cluster benefits are still often taken for granted rather than systematically documented. $(2005,5)$ 
This is surely true, and it is why we think that it is important to understand the challenges related to the process of development of clusters, since this process is not well documented and in our view largely determines the potential positive benefits. This analysis thus feeds into the objective of a comprehensive evaluation of clusters.

Let us recall that the cluster model developed in Canada by the National Research Council as well as the Innovation Systems Research Network is centered on the performance of firms and attempts to demystify the various factors that might explain this performance. The success or performance of a cluster is seen as being dependent on the performance of the individual firms that are part of the cluster, and this performance is moderated by cluster conditions and the environment of the firms. Among the factors that are seen as having an impact on the firms, let us mention human and social capital, research and development (R\&D) capacity and infrastructure, information infrastructure, community resources and support, as well as government policies and programs. This model is presented in a figure by Cassidy et al. (2005), but many authors have the same or very similar views. ${ }^{3}$ Cassidy relates the model to the various factors included in the Porter Diamond of performance, but he highlights the fact that Porter's definition of related and supporting industries has been enlarged to include public and nonprofit organizations that support cluster development; these are known as supporting organizations. This is similar to the industrial districts and innovative milieux literature, since these writings include many organizations that can act as supporting organizations. (Camagni and Maillat 2006).

In most writing on clusters, it is recognized that cluster development is a long-term process that is based on the mobilization of key stakeholders in the community or local or regional territory. In this context, Cassidy et al. $(2005,7)$ have identified four stages: latent, developing, established, and transformation. While many writings on clusters are centered on established, long-existing clusters, there is now a recognition that clusters can be at different stages and, particularly, that many are in the latent or developing stage in the new media or new creative industries (e.g., in the new media industry in Canada). ${ }^{4}$

It is also interesting to see how the various concepts present in cluster theory have been operationalized in different research projects. The Innovation Systems Research Network (ISRN) is probably the most important source of operational research on the subject of clusters in Canada (Holbrook and Wolfe 2002; Wolfe, Davis, and Lucas 2005). While the bulk of publications on the parent concept of innovative milieux is centred less on operationalization, the work by Julien (2005) is very much centered on operationalization of the concept of endogenous development and it complements the work presented by the ISRN group (Gertler and Wolfe 2005; Wolfe, Davis, and Lucas 2005). 
The main difference between this cluster view and other views of economic development or growth is the fact that it highlights the social and territorial nature of the innovation process; what has elsewhere been called "socio-territorial capital" (Fontan, Klein, and Tremblay 2005a, 2005b). This socio-territorial capital is seen as playing as important a role as economic or financial factors (price, financial support, and so on). The territory is seen here as being more than a simple repository for economic activity, and the role of social relations of production and interactions is highlighted. This explains that our analysis of the birth of a creative cluster will be largely centered on the analysis of social relations and interactions between actors.

\section{The Contribution of Human and Social Capital to Clusters}

It is one of the main functions of clusters to provide human capital and social capital, as well as financial capital and resources (although this is more commonly recognized in economic theory), in order to support firms that are part of the cluster. Beyond the human resources necessary for production, firms need moral and general support for their activity, and this often comes through social capital. Indeed, it is through interactions that representations and ideas are exchanged, and this supports firms and entrepreneurs in a given cluster (Julien 2005, 170).

The concept of human capital is well known, but that of social capital is less well known. While the origins of the concept are unclear, some consider that it originates in Jane Jacob's work The Economy of Cities. Julien (2005) insists on the definition given by the French sociologist Pierre Bourdieu, while recognizing the two previous contributions. In Bourdieu's work, social capital is defined as the set of resources that are related to the possession of a durable network of relations, more or less institutionalized, with "interconnexions" and "interexchanges"; in other words, this capital is related to the fact that one belongs to a group, a group of agents who are not necessarily characterized by common properties but by permanent and useful links (Bourdieu qtd. in Julien 2005, 170).

Some refer to the image of "glue" to indicate how these links and "interconnexions" function, as they can reinforce the relationships among members of a group or a cluster; others refer to the idea of a "lubricant" that accelerates the interrelations by instituting a climate of trust between the actors and imposing specific rules that are known and accepted by all. When there is a rich source of information (especially implicit or tacit information-as is often the case in film and audiovisual production, as well as other creative industries-rather than explicit, codified knowledge), interrelations and exchanges offer an excellent way of transferring this information to various actors; this facilitates the production of meaning, as knowledge is shared in a more or less diffuse way. In 
this context, the cluster is seen as a very efficient mode of access to information and to learning (Julien 2005,171).

As was highlighted in research on innovative milieux, industrial districts, and clusters, these links can be stimulating and can contribute to innovation, but they can also limit creativity if they are too strong and if cluster members limit themselves to the cluster rather than also being open to "global pipelines" of information (Gertler and Wolfe 2005; Julien 2005). It is thus important for these links and relationships to be not only global and not only local, although there is no clear indication in any work or research of how this correct balance can be achieved to ensure fruitful knowledge flows within the cluster. This is an important issue for analysis and has brought us to try to identify the types of relationships important for our creative sector.

On the basis of Lin's work (1999), Julien (2005) highlights how human and social capital function to support cluster development. Basically, the idea is that collective assets such as norms, conventions, and confidence facilitate accessibility and exchanges, and that these will in turn favor mobilization of cluster members. Accessibility and mobilization bring various benefits to cluster members; benefits can take the form of status or reputation effects as well as collective resources or support for given projects. This in turn will favor commitment and participation on behalf of members and, hopefully, development of the cluster. It is thus interesting to analyze the development of the film and audiovisual production cluster to see how precisely this process happens and what difficulties lie along the way. As mentioned above, much research has celebrated established clusters (Andersson et al. 2004), but the challenges related to their development often remain hidden.

\section{The Impact of Networks and Clusters on Learning and Human Capital Development}

Learning is an ongoing process that enables individuals, firms or territories to change and adapt to constantly changing conditions of their environment and is particularly important in the creative sectors. Various works have analyzed the varied impact of networks, districts, or clusters on learning. The work undertaken by Jacob, Julien and Raymond (1997) highlights four sources of learning that are related to the clustering process:

1) Clusters accelerate the circulation of information between members, especially when trust is important, and this both facilitates and accelerates the analysis of information, favouring business and cluster development.

2) Clustering helps firms to compare themselves, and this leads to a more competitive attitude between firms and to continuous learning and more innovation. 
3) Clusters offer new and non-routine information and facilitate multiplication and exchange within the group. The observation of others and the concentration of information from many sources favour the active search for new information (especially tacit information) and multiply the new ideas that support innovation.

4) When useful or needed, the cluster can transform competitive relations into cooperative relations, without completely eliminating competitive relations. (Qtd. in Julien 2005, 276).

Creative capacity and innovation are thus largely determined by interactions between socioeconomic agents and social learning in a given territory, and we thus wanted to see to what extent this is happening in the film and audiovisual sector in Montreal.

Many authors highlight the fact that social capital should be varied, in the sense that learning will be much richer if members of the network come from different environments and different backgrounds (Tremblay 2003). Also, for a cluster to be successful, it needs to offer a variety of sources of social capital, some contributing to financial start-up capital, some to psychological or social support, and others to new ideas and innovation.

In order for clusters to develop new ideas and innovation, they must be capable of adapting ideas according to their business needs. The ideas must also be compatible with the values and norms of the present and future members of the clusters, while being innovative and supportive of the evolution of values. Finally, the networks must be linked to other networks from other regions or localities in order to increase the richness and variety of information they offer and to help entrepreneurs join more complex networks (Julien 2005, 288). Here again, we find the idea that local buzz and activities are not sufficient, but access to global knowledge flows is important.

Research also highlights the fact that collective learning and the appropriation of rich information within clusters requires a specific atmosphere that is without uncertainty and ambiguity and that generates social capital and is a culture that supports creativity. Social capital is thus the basis for the territorial embeddedness of firms and clusters, which is why it can be referred to as socio-territorial capital (Fontan, Klein, and Tremblay 2005b).

\section{PROXIMITY AND CLUSTER ISSUES}

Since the 1980 s, there has been increasing interest in proximity and its potential effects on innovation as well as on the development and structuring of economic space. Authors such as Brusco (1994), Becattini (1991), Garofoli (1985) have emphasized the importance of geographical proximity in the success and development of spaces characterized as Marshallian industrial districts, as we saw earlier. Various authors, including Piore and Sabel (1984) and Benko and Lipietz (1992), have also highlighted the importance of districts and 
proximity as the source of innovation and the foundation of the development of so-called "winning regions," as Benko and Lipietz (1992), called them.

However, we must recognize that the effect of physical proximity on development has been called into question in recent years, as cluster theories were also questioned. Several authors have certainly identified the importance of unformalized compromises between actors (Salais and Storper 1993), institutional density (Amin and Thrift 1995) and the university-firms link (Grossetti and Bès 2001; Klein et al. 2005) in the differentiated trajectories of local milieux within a largely globalized economy. Storper (1997) even advanced the hypothesis of a new winning configuration for the third millennium - a configuration based on innovation, organizations, and territory. Must we therefore conclude that the simple concentration of actors coupled with physical proximity should be the principal bases for strategic action at the local level? Nothing could be less certain according to Markusen (2000) who, like the previous authors, suggests that while relations between actors (firms, decision makers, technology producers) are important, they are not the result of simply being closer together. In other words, the mere fact of cohabiting in the same territory is not a sufficient condition for actors to have relations with each other, as is also observed in recent work on Montreal clusters (Tremblay, Chevier, and Rousseau 2004). Moreover, some actors develop proximity relations without cohabiting in the same territory. This finding raises the question of the scale of the "local." What is the scale of the local as defined by actors when they characterize the network of their proximity relations? And is relational proximity not more important than physical proximity, as other authors have suggested (Tremblay et al. 2002; Markusen 2000)?

The concept of proximity is a key indicator for determining what socioeconomic actors mean by local space or local cluster. Thus it is necessary to examine the precise meaning of this notion, which we will do, on the basis of a rapid review of the literature on the notion of proximity.

In general now, there is more and more agreement on the fact that while physical proximity does not appear to automatically have an influence on a sector or a firm's capacity to innovate, access to information networks and personal interactions are key factors when a firm decides to develop innovations (Tremblay et al. 2002). In other words, although the fact of physically cohabiting with other firms is apparently of less importance than what was originally thought, it can have an influence on a firm's capacity to innovate if it also translates into relational or organizational proximity. The social, cognitive, and communicational aspects of a territory are considered by entrepreneurs to be vital in explaining the innovation taking place within firms of their sector (Fontan 2004; Julien 2005).

Territory was long perceived as a neutral geographical space. Firms are located next to each other, but their proximity by itself has little influence on 
their capacity to innovate. However, territory is now more and more perceived as a determining geographical environment when it is invested with resources - for example, a work force and a communicational climate - that can have a positive bearing on the development of firms. The geographical environment is what the population, organizations, and institutions that occupy it have made of it. Distance in quantitative terms is supplanted by the "proximal" quality of resources that are made available to the entrepreneur.

The increasing importance of the notion of proximity in the recent literature on the interaction between firms and on innovations leads some authors to refer to a "proximity economy" (Bellet 1992). This notion-which stems from a Marshallian perspective (Marshall 1889) and was used again in the 1980s by various authors 5 -initially referred to the concentration of firms in a limited space and has become polysemic (Kirat and Lung 1995). The analysis of the links between proximity and innovation has given rise to several approaches. Therefore, it is necessary to examine these diverse approaches in order to bring out the factors that are appropriate to the analysis of the attitude of firms toward cooperation and innovation. What type of proximity are we referring to in relation to innovation and clustering? Are all forms of proximity determining factors in the localization of firms and their decision to cooperate and to innovate?

\section{From Physical Proximity to Institutional Proximity}

Physical proximity is the simplest form of proximity. It refers to the localization of firms and institutions of higher learning (e.g., research centers and universities) in a given space. The principal measure of this proximity is the distance that separates actors from each other. Spatial proximity refers to the hypothesis that the greater the number of local firms, the more opportunities for cooperation in problem solving, and the denser the local exchange relations, the more they speed up the research process of individual firms and the accumulation of technological and other knowledge (Haas 1995). Proximity among actors thus becomes a guarantee of accessibility to scarce information (Planque and Py 1986), a spatial insurance (Veltz 1996). While physical proximity is clearly not a sufficient condition for establishing collective dynamics, it establishes a potentiality that makes social contact possible (Colletis and Winterhalter 1991; Kirat 1993).

The second form of proximity is relational or organizational proximity, which is a notch more complex than simple physical proximity. It implies that firms and organizations, in their collective dimension, either share or do not share the same schema of thought, production, communication, and innovation. The existence of organizational proximity means that groups of agents, a priori independent, set up coordination procedures in order to achieve goals that 
were agreed on. Organizational proximity appears inside organizations (firms, establishments, etc.) and, where applicable, between organizations linked by a relationship of economic or financial dependency or interdependency (between companies that are members of an industrial or financial group, within a network, etc.).

Organizational or relational proximity is characterized by a dual dimension. The first dimension refers to a proximity of similarity or of common references (Pecqueur 1989), while the second dimension refers to the frequency and the quality of interactions among separate organizations (external coordination between organizations). These dimensions are reflected in the building of common knowledge that facilitates the collective learning process, leading to, for example, the construction of new resources or the development of opportunities (Amendola and Gaffard 1988). Thus this is how the notion of learning by doing can emerge, on which the mechanisms that lead to the construction of a collective memory are based. ${ }^{6}$ This concept can also be based on the writings of evolutionary authors, such as Lundvall (1988), who highlight the interactions between users and producers.

Relational or organizational proximity is thus immaterial and nonmarketable; it is supported by multiple relations outside the market. In addition, it can be independent of all spatial dimensions. The conditions for the appearance of organizational proximity can be favored by physical proximity but can also be penalized by the latter, as is the case of multimedia firms that jealously protect their technologies and do not necessarily exchange a great deal of information, even when they are geographically concentrated (Tremblay et al. 2002).

A third type of proximity is technological proximity, which is in line with a logic similar to that of organizational proximity. It corresponds to a specific conception of technology, that of evolutionary authors, which reviews the microeconomic bases of innovation (Nelson and Winter 1982; Dosi 1988). According to evolutionary theory, innovation is endogenous, taking the form of continuous and gradual changes in an incremental process, such as a set of routines $^{7}$ and selections built up through trial and error processes. Based on this approach, production organizations have the specific knowledge and know-how that give the notion of technology a dimension of collective knowledge that is shared within the organization but cannot be immediately appropriated by the environment.

Technological proximity can thus constitute one of the bases of inter-firm cooperation, and it is on this basis that collective learning can appear between firms participating in a production system or cluster (Dupuy and Gilly 1996; Kirat 1993). Just like organizational proximity, technological proximity can be favored by physical proximity, since, besides reducing transaction costs (Scott 1999), it can facilitate cooperative relations, but it is not always the case. 
The fourth and most complex form of proximity is cultural or institutional proximity. It implies that entrepreneurs share the same representations, rules of action, and values. This form of proximity is closely linked to interactions between firms and agents through a collective learning process. This collective learning process may involve physical proximity between agents, insofar as this proximity is a condition for forming long-lasting relationships. Proximity is favorable to exchanging noncodifiable knowledge (habits, routines, conventions) or, in other words, knowledge that cannot be transferred in space by technical supports.

\section{Territorial Effect of Proximity}

The different forms of proximity described above define the many scales of action of firms, thus circumscribing their innovation territory. A firm's innovation territory results from and is defined by the superimposing of the different forms of proximity, thus forming a territorial innovation system. In this way, the territorial mechanisms of coordination and interrelation between firms are established through processes that include partnership, sharing of social networks, collective sanctions, concentration of information, informal codes that enable expectations, frequency of contacts, and construction of relations of trust.

This is what Marshall was referring to when he suggested that the relationship between the firm and its immediate environment structures the processes of learning and industrial cooperation, leading to the creation of new resources. Today, this immediate environment is somewhat different from that observed by Marshall. It has become more complex and, especially, is organized into a spatial hierarchy (from the local to the global). While being geographical, its scale is associated with cognitive information structures or variable practices that cannot be easily codified or routinized.

This is where the link between proximity and innovation comes into play, because the process of knowledge acquisition is a process of conceptual construction based on elements of experience. Learning thus becomes a process that arbitrarily combines existing experiences leading to the creation of new concepts that are more effective in terms of solving a particular problem (Dupuy and Gilly 1996). Individuals do not simply collect information, but also transform their representations when formulating hypotheses or making conjectures about their environment. Learning is an emergent process-that is, a process whose overall effectiveness is greater than that which results from the simple aggregation of specific information: "Knowing does not merely involve storing information. It also means being able to mobilize it, use it in our inferences, because having information does not give us the means to interpret it or to know it" (Julien and Marchesnay 1996). 
Proximity in all its complexity thus becomes actors" "spatial intelligibility" (Pecqueur 1996). Actors who are looking for solutions proceed by trial and error. These trial and error processes are all the more likely to produce solutions, as they are conducted in a spatial reference with variable structuration. The principal vehicle of this learning can be the so-called local physical proximity, which allows multiple contacts (Colletis and Pecqueur 1993), but it can also be other forms of proximity. The territory is thus structured in a reticular way between the different physical units of expression of proximity as a scene of the social link between production firms and organizations. This link can be strengthened in a local framework (Tremblay and Fontan 1994). However, what does the word local mean in a context of reticular networks; networks that are, moreover, located in places as far as Boston, New York, Los Angeles, Paris, or London. To view proximity in this way is to pose the question of the local scale that is pertinent to the development of clusters, a question that remains open to this day, and, more and more, it appears that relational proximity appears to be as important as physical proximity, at least in creative sectors such as multimedia and films.

\section{THE CLUSTERS STRATEGY OF THE MONTREAL METROPOLITAN COMMUNITY (MMC)}

The policies espoused by the Montreal Metropolitan Community (MMC)—or Communauté métropolitaine de Montréal_-since the 1990s support the idea of a network-based local development (Rifkin 2004) or cluster strategy (Gertler and Wolfe 2005). The current mayor of Montreal, Gerald Tremblay, introduced the concept of clusters in Québec policy in 1991, a model which, he said, "is designed to stimulate the creation of conditions within which new ideas and processes can pass from embryonic to commercialized stages and provide returns for stakeholders" in 1991, as Québec minister of industry, commerce, science, and technology (Montreal Metropolitan Community 2008, 6).

After almost twenty years since the first presentation of the concept, this strategy has brought the city of Montreal to define for itself four clusters to be supported actively by policy: the aerospace industry, born in 2006 after a concerted effort spread over two years; health sciences, which was recognized by MMC policy in 2002; the information technology and communications sector launched in 2002; and, finally, the film and audiovisual production cluster. Together, these clusters represent a total of 238,000 jobs distributed between approximately 6,363 institutions, businesses, and organizations belonging to these four sectors (Montreal Metropolitan Community 2008, 14-15). 
Who oversees the development of these clusters within the MMC cluster policy? The MMC is responsible for the strategy and so serves as the coordinator of the three fundamental steps in the creation of a cluster: pre-startup, startup, and operation. One of the conditions for eligibility for the MMC and its governmental partners to lend financial support to the secretariat of the cluster is that all of the industries' stakeholders have to be part of one nonprofit organization run by a board composed of the sector's professionals.

In the case of the film and audiovisual production cluster, the organization set up to oversee its activities is the Québec Film and Television Council (QFTC), an independent body that receives monies from the MMC after having signed agreements outlining the allocation of funds for specific projects. The QFTC receives two equal installments and a third, which represents 10 percent of the allocated funds, disbursed at the reception of the project report. The relationship between these two organizations remains independent, as it is the QFTC that has close ties to the field and that is solely responsible for the completion of the projects.

This development strategy is based on the mobilization of the principal stakeholders around a leader or champion willing to rally the community around a common goal. The objective is to allow Montreal to project the image abroad of a city of knowledge, as well as a creative and prosperous city. The European Union's interest in these practices, which led to the development of the Cluster Network (CLUNET) beginning on September 1, 2006, is considered by many to be proof of Montreal's influence in this field. The three-year international project, coordinated by the North West Development Agency, aims to create a network of the most innovative regions with clusters. CLUNET is composed of sixteen partners, including Montreal, the only non-European participant, and the main objective of the network is to launch pilot projects fostered by international cooperation "to achieve a common agenda for Europe that will lead to the creation of world-class clusters delivering global competitive advantage in lead markets" (Cluster Network 2007.)

The internationalization of expansion into new markets demonstrates a willingness to explore all the means necessary to prevent the cluster policy from becoming merely a regional development tool and, instead, bring renewed investment into the regions they represent through the strengthening of international ties and the exploitation of the theory's full potential. This stems from the recognition of the fact that clusters need to be based on international links as well as local relations. The first potential pilot program was launched at a conference held in Montreal in September 2007 entitled Europe Meets America. The conference focused on the cooperation between the aerospace industry clusters in Hamburg, Berlin, and Montreal; a second alliance is based on a group of eight pilot projects based in both Tuscany and Montreal, which focus on transnational commercial incubation of businesses. 


\section{A New Model for Film and Audiovisual Production in Montreal}

It is in the context of this cluster policy development in Montreal and the issues related to the various forms of proximity that we decided to study the film and audiovisual cluster's pre-startup stage to explore how Montreal, a city which built it's industrial strength largely on the aerospace industry, health sciences and information technology and communications clusters, is in the midst of creating, or rather actively supporting, a cultural cluster. ${ }^{8}$ The objective of the cluster policy is to develop a creative cluster based on stimulating the density and quality of the exchanges between the main stakeholders involved in the film and audiovisual sectors. It appears that relational proximity and knowledge flows were rather easily developed in a concentrated sector such as aeronautics, but it is interesting to see if they are as easily developed in a much more diffuse sector, such as the film and audiovisual cluster. We therefore analyzed the recent developments observed in this sector to determine to what extent physical or relational proximity is playing a role in cluster development here.

Let us start by mentioning that the Forum métropolitain de l'industrie cinématographique (FMIC), which took place in Montreal in November 2004, represents the first concerted move toward the construction of a common vision and drafting of a development plan. The objective of developing a strategy that would protect Québec's interests on the international scene and ensure the development of local production is a fundamental move to counteract the weak position in which the industry found itself at the beginning of 2003. Indeed, the strong competition between Québec and the other Canadian provinces and American states, as well as the strength of the Canadian dollar, which in itself reduced the attractiveness of the Canadian market to American film production teams, created the framework for some cooperation and recognition of the importance of participating in this forum.

The event was orchestrated by the MMC, which had allocated funds in its 2005 budget to provide the necessary financial support to create the executive of the cluster and to foster value-added projects that were backed by a consensus throughout the industry. Other partners who took part in supporting the creation of these executives included the Government of Québec, the Government of Canada, and the private sector; each was to contribute 25 percent to the total amount of 18 million Canadian dollars allocated to this project. However, in November 2007, the project lost one of its main backers: the Government of Canada. The Conservative government issued a note stipulating that it was to cease funding nonprofit organizations directly. Thus the executive of the film and audiovisual cluster, which had taken the form of a nonprofit organization, lost one quarter of the funding necessary for its development. A study by E\&B DATA (2004), which precedes the FMIC by a few months, reported 
on the health of the film and audiovisual production portfolio in Montreal and Québec by highlighting that the industry, characterized by the great quality and breadth of its talent and technological knowledge, is on the cutting edge and, as such, has the potential to be positioned as one of the most dynamic sectors of the Québec economy. The structure of the portfolio is quite complex as it includes all production, for both film and television, arranged into four categories: production, broadcast, institutional complementary activities (finance and training), and support (visual software or audiovisual equipment, technical services). These categories represent a total of 35,000 jobs and more than 500 businesses in the production and broadcast categories alone (E\&B DATA 2004). This multitude of localized stakeholders represent the critical mass needed to put the film and audiovisual cluster into action and foster the needed synergies and pooling of strengths to ensure the creation of a collective force. It was presumed by many that physical proximity between the actors would lead to relational proximity and that this would easily foster cluster development and especially knowledge flows; our research shows that things are not always that easy in cluster development, even when physical proximity is present.

For many of the Montreal film and audiovisual actors, this cluster strategy is seen as crucial. It represents "a new way of thinking about national, state, and local economies ... [that] necessitates new roles for companies, for various levels of government, and for other institutions in enhancing competitiveness" (Porter 2004). The aggregation of companies who cooperate and contribute to revitalizing their sector is a response to the new network-based economy, one in which companies have to demonstrate their ability to create alliances within their industries in order to assert their competitiveness in the market. To do so, they must undergo a transformation for several years until the beginning of a new project, thus beginning a larger process of change that will ensure that they never exist in the same form again (Rifkin 2004).

This trend touches upon all sectors of the economy but is most apparent in the striking example that the film industry presents, because of its transition from a model encompassing companies vertically integrated to a model with a multitude of small and medium enterprises or businesses (SMBs) and independent producers. These work together on a project basis, while improving their performance in terms of flexibility, specialization, continuous learning, and inter-company cooperation (Friedman 1995). Salvemini and Delmestri (2000, 59-73) define a third way-a governance model based upon collaboration between stakeholders and coalitions, in opposition to the classical model of a limited number of forces in play and the "invisible hand" that coordinates, in contrast, the specialized activities of a large number of smaller stakeholders. According to these authors, the "de-verticalisation" put in place by the Hollywood industry, in terms of advantages to the 
competitiveness of the sector, "has also created a split between the different sectors of the labor market, between core and peripheral workers, between the privileged ones who control access to work and the people who are manipulated to accept bearing the increasing uncertainty of the sector on their shoulders" (Salvemini and Delmestri 2000, 68-69). However, according to Ferriani, Corrado, and Boschetti (2005, 257-285), when it comes to the nature of the collaborations that begin and end extremely quickly within the context of "temporary creative systems," the reiteration of contacts that takes place provides a certain stability and continuity in the context of latent networks (Starkey et al. 2000), within which "there is a relationship between shared experience, the emergence of a collective mind and the stock of collectively held tacit knowledge" (Berman et al. qtd. in Ferriani, Corrado, and Boschetti 2005, 274).

It is in this context that the QFTC was given the mandate to act as the cluster policy lever for the sector. In 2007, the board of this organization created a consultative committee and gave it the mandate to study the dynamics and orientation of the group of firms present in Montreal—possibly a cluster-in order to provide a guide for the development of the film and audiovisual production industry along the lines defined above. This work to develop a really active cluster - and not a simple collocation of a group of firms - was divided into five areas: labor, foreign investment, innovation, image/visibility/outreach, and strategic planning.

We need to mention here that the QFTC is an organization that has responsibilities at the level of the whole province of Québec, but there are also other similar bureaus at the regional level: the Montreal film and TV commission, the Laurentians Film and Television Commission and the Ottawa-Gatineau Film and Television Development Corporation (OGFT). The latter covers two provinces, Ontario and Québec, and is not included in the Montreal cluster because of its obviously divergent interests. The Montreal and Laurentians film and television commissions are on the contrary very active in cluster development. Their main role is to give information to local and foreign producers, to support film projects in their region, to promote the City of Montreal and Laurentians regions in the film industry, and to support the international strategy of the QFTC.

\section{RESEARCH OBJECTIVES AND METHODOLOGY}

In the case of the film and audiovisual cluster based in Montreal, our exploratory research analyzes the strengths and weaknesses that appear in the pre-startup phase of the cluster and tries to determine how proximity of the actors plays out in this development. Considering the theoretical elements presented above, on proximity and clusters, our research addresses the issue of proximity relations, interrelations, and knowledge flows, both locally and with 
external sources, which have an influence on the cluster. Our research globally seeks to understand how cities create networks, as well as specialized organizations whose role is to foster the development of knowledge flows between the clusters present in the regional economy and between local and non-local stakeholders. Consequently, the main research hypothesis is that the performance of cities, in relation to the economy and creativity, rests upon the capacity to develop relational proximity and also on the following elements, which may also be a function of the importance of relational proximity:

1. The intensity of the local knowledge flows within these industries/clusters.

2. The intensity of the local knowledge flows between these industries/clusters.

3. The importance of the links based upon the knowledge of economic stakeholders at local and non-local levels.

Since the film and audiovisual cluster is not yet fully established, we concentrate here on the creation of links between actors and knowledge flows within the cluster. To analyze these elements, we contacted several key stakeholders who took part in the creation of the cluster, as well as the QFTC and a few other associations that are not members of the QFTC but have an important support role in the film and audiovisual industries. Besides the QFTC, there are training organizations, unions, financing bodies, and public institutions. We contacted these organizations and identified the main stakeholders of the sector and undertook a series of fourteen interviews with persons who hold positions within the main governing organizations of the film industry. We have also undertaken a comprehensive review of the existing research relating to Montreal's film and audiovisual production cluster, and we have developed an interview grid based on elements derived from the ISRN project on clusters, as well as the Statistics Canada survey of innovation.

The results presented in this section cover qualitative data related to the three following themes: the dynamics of local governance, the role of government, and knowledge flows. For each of the three themes, we concentrated on elements related to the start-up phase of the clusters, as well as the main strengths and weaknesses observed after the initial phases of concertation and creation of the cluster. We were able to identify the factors that appear to favor collaboration, exchange, and work within the clusters, as well as the main obstacles.

\section{RESULTS}

Our research is based on semi-structured interviews with representatives from various organizations, that are from Film Production, Union Associations, 
Film Offices, a training center in Film and Audio-visual, Service providers to the film and audio-visual industry, as well as affiliated corporate and individual members of Québec Film and Television Council.

The interviews emphasize the importance to all of the stakeholders involved in the cluster, who must partake in inclusive and collective projects, of making sure that that the Made in Québec film and audiovisual production industry can take full advantage of this new organizational model. By recognizing the role of the cluster strategy in the process of developing synergies within the sector, the stakeholders involved in the cluster who were interviewed see an improvement in the relationship between different organizations over the last years, especially since the recognition of the cluster within the MMC cluster policy. The relational dimension comes out clearly from the interviews, with many respondents highlighting the fact that relational proximity is more important than physical proximity in developing relations and an active cluster. Many also highlight the fact that physical proximity does not automatically lead to relational proximity and that the latter is oftentimes complex and difficult to nurture.

It's a principle that people understand better now than they did, but not everyone is ready to put it into practice. So, the relationships are better, but it's still up to the individual. For example, with an organization that is collaborative, if one of the individuals involved has certain insecurities, he or she will have the tendency to not participate collaboratively so as not to lose his or her control over the situation. (Manager at the Montréal Film and Television Commission)

When creating a cluster we always say that there are three key factors: mobilization, mobilization, mobilization. So, if you aren't able to involve enough leaders and stakeholders there is no momentum. (Manager at the Montréal Film and Television Commission)

Collective mobilization thus appears crucial, and according to stakeholders, it appears crucial to "sell Québec" first and then the specific region. The relationships between the different film and television councils present in Québec are thus moving in this direction. The fact that the QFTC has a mandate for international development has rendered it more neutral, as it represents everyone. In the past, there were only regional offices that functioned independently and competed with each other. This situation arose mostly because of the diverse budgets available to the various offices that prevented the creation of any positive synergy.

We work together to put together the best bid possible so that we get the project in Québec and when it (the production) arrives it might be shot in different regions of Québec; ideally it's shot in different regions of Québec and everyone gets their piece of the pie, but they have to first decide on coming to Québec! (Manager at the Montréal Film and Television Commission) 
What is clear from all of our interviews is that because the film and audiovisual production cluster in Montreal is still in the start-up phase and is definitely not an "established" cluster, to use the words of Cassidy et al. (2005), the dynamics of the collaboration between the members of the QFTC are not yet fully developed. At present, we can regard this cluster as an embryonic structure, at the start-up or "developing stage" (Cassidy et al. 2005); relationships between the actors are not yet fully developed and the cluster is still searching for its own development model, as other industrial clusters in Montreal did in preceding years. As mentioned above, this is precisely one of the interests of this research - to better understand the challenges related to the creation of a cluster and to the development of proximity relations, knowledge flows, and synergies between members of the cluster.

Based on the interviews, there are still a few obstacles to collaboration, and it is also possible that other actors should be brought to the table to collaborate, many of whom are not yet active members of the QFTC. The groups that are identified are important financial actors, such as those who are involved in the management of real estate and the stakeholders who are closely involved with the tourism and other commercial sectors, since many believe there are interesting synergies to be developed with these groups in relation to the film industry. Again, relational proximity needs to be developed with these actors, who are on the fringe of the industry but could contribute to the development of the cluster.

We are having difficulties with regards to setting up shoots on their property either because the whole idea is new to them or because they are not open to the idea in the first place. I'm thinking of institutions such as Central Station, Canadian National, who could give us access to some exceptional buildings for our projects, but we have a hard time getting our contacts with them. Banks as well. Even though we need these guys to become a truly international destination. (Development Officer, Québec Film and Television Council)

It's pretty clear that in this milieu there are interesting spin-off effects for restaurants, hotels, shops, boutiques, etc. Is there a way to get these people to come to the table? In the same way that they were open to it for the Grand Prix? Is there a way to get these people to come to the table and talk more seriously about their interest in supporting this whole approach? (Development Officer, Québec Film and Television Council)

As to the first steps of concertation or consensus-building, the interviews reveal a relatively positive attitude toward developing relations within the industry, as well as a fairly relaxed climate. This attitude is due to the stakeholders' decision to associate themselves with the film and audiovisual production industry in Montreal after recognizing that being at the table is important to creating synergy within the sector, or simply because they wish to imitate the leaders in the sector. This imitation effect is not negligible and had also been 
observed in the aeronautics and health sciences sector. If the main actors are there, the others follow and relations develop more quickly between the various actors because of the leadership and impulse given by the most important actors. The challenge in the film and audiovisual sector is that it is composed of many more small players, and the leadership is not so easily identified or does not have as quick an impact, as is the case in more concentrated sectors. However, relations and cooperation have been building, even if some mention a few conflicts when forgetting the general good in favor of their own personal interest. Thus it needs to be recognized that relational proximity sometimes leads to conflicts and competition as well and is not always a smooth process of increasing collaboration between the actors.

In the majority of cases, these are friendly meetings, even more so because it has been a few years and many of the people have become more mature and have understood that if everyone works independently we'll never get the same result that's possible once we work together in a coordinated way. (Development Officer, Québec Film and Television Council)

There isn't a lot of conflict. What's important is to define what we need from the cluster, to make sure that we are looking out for the interests of the group and not for our individual interests. (Development Officer, Québec Film and Television Council)

However, several significant elements come to light when evaluating the possibility of a larger mobilization of the main players in the film and audiovisual production industry, and these highlight some challenges in getting all players around the table, since many may have conflicting objectives at times.

There are several key players: the film and television producers of Québec (APFTQ), the artists' union (UDA), the unions, the producers, and often all of these players have different objectives—sometimes conflicting objectives. There are also some groups that are more interested in producing cultural products, meant for a local market, and others with a more commercial orientation. I think that there is a fear that some groups feel that they might take a backbench to another and that is why it's important to remember that the success of one doesn't always mean the defeat of another. (Manager from an organization which finances firms in the cultural sector)

The communication of the stakes of each player needs to be transparent so that the interests of all are taken into account. (Manager from an organization which finances firms in the cultural sector)

Everyone needs to be able to get their point across, but, at the same time, sometimes there needs to be an arbitrator to make sure that the interests of the whole cluster are respected. What's inconvenient is that this sometimes brings out rather important differences between the stakeholders' objectives. It's a difficulty that has to be faced. (Manager from an organization which finances firms in the cultural sector) 
Within this framework, the dual role of the QFTC becomes even more important: it must jointly assume the role of an international promoter focused on championing Québec's attributes in foreign markets in order to attract business prospects, as well as acting as the executive of the film and audiovisual production cluster in Montreal. The QFTC thus has a two-fold role: one that is at the international level and another that is a regional and economic development portfolio directly tied to the strategy of Montreal's industrial clusters.

The first mandate of the QFTC leads it to put forward international promotional activities, such as the promotion of the aspects of film production in which Montreal is specialized (visual effects, animation), and that give Montreal a competitive advantage. In the QFTC's second role, it develops information sessions on issues of tax relief as well as training and professional development projects. Among other initiatives, we can mention the national photothèque, "which will be part of an elaborate system, which integrates, in a pointillist manner, thousands of photos of shoot locations" (Bureau du cinéma et de la television du Québec 2007). This responds to the need to promote Québec and attract foreign producers, along with the need to promote the interests of those who wish to undertake local projects. All these concrete initiatives aim at developing a feeling of identity and ownership in the sector, as well as relationships based on proximity of the actors in terms of interests and objectives.

We can see, however, that this variety of projects could create problems for some stakeholders if they feel threatened by the information-sharing dynamic and policies of the group, which could come into conflict with their own individual goals and interests. For example, the artistic and commercial communities can come into conflict on some issues, especially on funding issues.

One of the elements is that there is a lot of government money spent in this sector and there is a fear that if the government puts more money into the commercial portfolio, the purely artistic portfolio will suffer because there is a limited amount of funding available. (Manager at the Montréal Film and Television Commission)

The major barriers are to make sure that people can see past their own interests and that the perception of the government and the rest of society is favorable, because it takes a great deal of government support, and support from other economic sectors who are in tune with our development so there isn't a sense that we are getting handouts instead of taking care of ourselves. (Development Officer from an organization which finances firms in the cultural sector)

However, these often conflicting elements, which must be managed very carefully, are not only limited to the opposition between local and national interests, or the opposition between cultural and commercial views on the issues. There are other dichotomies that emerge when studying Montreal's film and audiovisual production cluster. The first concerns the relationship between local producers and their tendency to under exploit the visual effects and 
animation companies that exist in Québec, as well as the technology sector, which is highly competitive on the international scene. Why don't local producers take advantage of these resources, resources that remain unrecognized in categories at the Jutra Award, ${ }^{9}$ or for that matter at the Genie or Gemini Award, on a national level? There are several conflicting answers:

For productions in Québec, the budgets are so small that they can't take advantage of the visual effects facilities or major studios in Montreal. Québec films have a budget of 2 or 3 million, which is tiny. Local producers know what's out there, it's all a question of budget. (Director of a film company)

One of the problems is that too often visual effects are related to post-production; we have to educate people so that they are more likely to include visual effects in their pre-production schedule. So there are still production people left to educate. (Director of film company)

Another issue that was brought up throughout the interviews, which has an impact on the development of the film and audiovisual production cluster, is the issue of communication between generations; some conflicting views are attributed by some actors to age or training, which appear to constitute a determining factor in how individuals structure their businesses. Age differences might lead to different business strategies and, consequently, to more or less relational proximity between some actors.

If you look at visual effects, there has been a bit of a bottle neck for a while-what I mean is that the large companies that have been here for a long time really think in terms of "our" employees, "our" contracts, "our" clients and "our" technology ... there is no exchange ... but now there is a new generation of entrepreneurs who are willing to share. They are of my generation: people who have worked for others and are now setting up their own companies. (President of a film company)

The people who responded quickly and mobilised were from the visual effects industry - probably because they had an organisation that looked after them and made sure that their activities were integrated with those of the QFTC. It's a young industry, with young management, who really saw the value in collaboration for the good of their industry. (President of a film company)

There therefore seems to be a generational effect and apparently a stronger relational proximity and inclination toward cooperation in the younger small businesses, but the greatest weakness in the visual effects and animation sector in Québec is the lack of recognition they receive from governments, especially in contrast to the amount of attention payed to another sector to which they often compare themselves: video game production. While this latter industry remains in the media spotlight and is often cited as a source of innovation by the city of Montreal, the visual effects and animation industry remains in the shadows. This is due in part, according to our interviews, to the lack of promotional planning and activities, especially when compared to those of the 
video game industry. In the case of visual effects and animation companies, the development of the cluster is seen as an opportunity to be proactive and raise the profile of their industry, not only internationally, where their success is well known, but also locally, where it appears less known. By adding these elements to the inter-generational element, it becomes clear that those who joined the cluster early, other than the younger businesses, are those who need opportunities to create synergy within the industry and to project a stronger, more proactive image.

Over the last 4 or 5 years, there has been a lot of talk about video games; there has been a lot of lobbying and campaigns to promote the position of Montreal within the industry. Absolutely, we see much less of an effort going into the promotion of post production and I could see there being more work to do in this area. (President of a film company)

There isn't a lot of recognition coming from either level of government, either Federal or Provincial. The video game industry took up a lot of space and they have done a great job of lobbying since the end of the 90s, with the advent of Ubisoft, for example. So there is obviously some kind of collaboration with the various ministries, but they have not recognized the innovative aspect of our industry. (President of a film company)

However, the video game industry is not only a competitor of the visual effects and animation sector, but also a collaborator, spurred in part by the purchase of Hybrid Technologies by Ubisoft in July of 2008. Hybrid Technologies is well known as a company specializing in visual effects for film, most notably the films 300, Sin City, Voyage to the Center of the Earth and the Spy Kids franchise, as well as the production of television programs and advertorials. The convergence of these two companies will lead to new collaborations on video games and films in a market evaluated at 12 to 15 million Canadian dollars a year. Many consider that this will help the film and audiovisual cluster to become better known and develop collaborations with other creative sectors, starting with the video game industry. Indeed, relational proximity might sometimes be closer across clusters than within clusters. Video games and visual effects might feel a stronger relational proximity than that observed between visual effects or animation and TV in general, or cinema in general.

You have to understand where the film industry is going ... what is the future of the film? In what context will we be in if we wish to remain competitive over the next five years? The technology is evolving very rapidly and the convergence that we see between video games and film will perhaps create new experiences for viewers. You have to be interested in the process and the division of work in the context of innovation and new routes. Will we continue to remain passive or will it become a more and more interactive experience? Will this lead to a hybrid between films and video games? (Chief Executive Officer of a training center in audio-visual and film) 
The boundaries between these two creative sectors appear more and more permeable, in particular for firms of cutting-edge technology, and this complicates the start-up process of the film and audiovisual production cluster. It is not a simple task to instill a unified vision and sense of belonging within a cluster. When each player has so many interests at stake, they lack confidence in the collaborative process and sometimes see it as an invasion of their territory. These are the main challenges that are observed in the context of the start-up phase of this cluster.

\section{CONCLUSION}

According to many actors in the sector, the film and audiovisual production cluster of Montreal could fully exploit all of its potential for development in local markets by structuring its start-up and operational phases to include as many players as possible. This would mean that the strategic direction agreed upon would truly encompass that of the industry as a whole and that the important players who remain on the sidelines would have to position themselves clearly in relation to the cluster. This is indeed an important challenge in terms of relational proximity and highlights the fact that the pure physical proximity of the actors - the fact that many are concentrated around the television production districts and in the Montreal metropolitan area-in general does not suffice to create a strong relational proximity and foster a healthy cluster.

The Forum métropolitain de l'industrie cinématographique (FMIC), which took place in November of 2004 and put into motion the process of development of the cluster, was mentioned in several interviews as a much appreciated effort, particularly by those who saw the need for a concerted effort during the difficult times the Montreal film and audiovisual industry experienced in 2003. However, this does not suffice to develop relational proximity and a strong cluster. More frequent interactions and work in common are needed in order to attain this objective, and this cannot happen overnight. Time is needed to develop this relational proximity and to foster the development of an active cluster.

However, the delays due in great part to the federal government's retraction of funds allocated to nonprofits, which put off the presentation of the cluster and the QFTC's business plan until January 2009, left many actors in the dark about the progress of the cluster. This left many feeling that the cluster was a rather abstract concept, since relations between actors were not activated in any way.

It appears essential to many to step up efforts in this area so that the film and audiovisual cluster can work with a better sense of synergy between its numerous stakeholders in the region in order to reduce the time that public institutions need to gather information, report back, and respond to the needs of the region. What often happens is that by the time the information gets to the 
agencies, the sector is already in crisis or the information is no longer pertinent. This is an unacceptable situation in an industry whose size and dynamism are often surprisingly great.

The reality is that Québec represents a small market, where the players are very familiar with each other; while this can be seen as a source of synergy and relational proximity, this does not prevent tensions and conflicts, as mentioned above. The management of these conflicts is an important step in making sure that the performance of this sector feeds off of the intensity of the local activity and the awareness of both local and non-local economic factors. The winning strategy for a cluster appears to be to assemble the greatest number of stakeholders within its structure, to have access to multifaceted points of view, and to develop relational proximity, possibly on the basis of physical proximity, but not only; the cluster must also make efforts to solve conflicts and reach some form of consensus on its future and on the main actions to be taken.

To return to our theoretical elements, we could say that relational proximity is only beginning or that social capital—as defined in Bourdieu's (1980) work as the set of resources that are related to a durable network of relations, with "interconnexions" and "interexchanges"-is only beginning to develop in this sector. However, many actors have seen enough common interests to start moving in the direction of cooperation and exchanges, many of them based on relational proximity.

We mentioned earlier the image of glue to indicate how these links and "interconnexions" can be useful, since they can reinforce the relationships among members of a group or a cluster; it is clear that to this day, the actors of the film and audiovisual cluster are not glued together, although some have started to develop connections and social relations.

In reference to the image of a lubricant that accelerates the creation of relations between actors, we can say that the activities of the film and audiovisual cluster have contributed to an acceleration of the relations and connections by instituting a climate of trust between the actors. These activities have also imposed some rules that reduce conflicts and favor cooperation, as well as put forward the general interest of attracting film productions to Québec and distributing them in different regions.

We can thus conclude that the film and audiovisual cluster is at the startup or development stage, that it has accelerated the circulation of information between members of the sector, and that it has contributed to some development of relational proximity, as well as to learning and innovation (innovation usually coming later, when clusters are more established and connections between actors more developed). However, there are still efforts to be made to ensure the cooperation of many actors that are not directly in the cluster (tourism and film location actors such as real estate firms), as well as to ensure the 
transformation of competitive relations into cooperative relations throughout the cluster. Clearly, the actions to date did not suffice to develop a very strong relational proximity and a strong, mature cluster. There need to be more frequent interactions and work in common in order to attain this objective, and this cannot happen overnight. Time is needed to develop this relational proximity and to foster the development of an active cluster in the film and audiovisual sector.

\section{KEYWORDS}

audiovisual, cluster, film, Montreal, proximity

\section{NOTES}

1. The multimedia sector in Montreal benefitted from the Multimedia City program, which gave important financial incentives for firms to establish in the Multimedia City; if they did, they benefitted from financial contributions for each worker hired (Tremblay, Chevrier, and Rousseu 2004; Tremblay and Rousseau 2005). The program ended in 2008 and there is no similar program in the film and audiovisual sector.

2. In comparison, the aeronautics cluster is composed of a few large firms that are at the top of the pyramid and use the services of many subcontracting firms. The cluster is thus much more easily integrated and its boundaries are much clearer than is the case in the film and audiovisual production sector. This makes it all the more important and interesting to study a creative sector that is composed of an important diversity of actors and firms.

3. See Julien 2005; Holbrook and Wolfe 2002; National Research Council 1998; Padmore and Gibson 1998; and Wolfe, Davis, and Lucas 2005.

4. See Britton, Tremblay, and Smith 2009; Britton and Légaré 2004; Smith, McCarthy, and Petrusevich 2004; Tremblay, Chevrier, and Rousseau 2004; also, more generally, on other clusters, see Gertler and Wolfe, 2005.

5. See Piore and Sabel 1989; Becattini 1991; Benko and Lipietz 1992; Courlet 1994; and Brusco 1994.

6. When Marshall talked about the presence of quasi-organizational rent, he was referring to this level (Lecoq 1993).

7. Routines are interaction models that constitute effective solutions to specific problems. These interaction models are specific to group behavior, although some inferior routines might be specific to individual behavior (Dosi, Teece, and Winter 1990).

8. It can be considered that the cluster already exists, although interactions are not necessarily as active as they should be. The MMC cluster policy aims precisely at increasing these interactions and knowledge flows.

9. The Jutra Award is awarded annually to films from the Quebecois part of the Canadian film industry.

\section{REFERENCES}

Amendola, M., and J. L. Gaffard. 1988. La dynamique économique de l'innovation [The economic dynamics of innovation]. Paris: Economica.

Amin, A., and N. Thrift. 1992. Neo-Marshallian nodes in global networks. International Journal of Urban and Regional Research 16 (4): 571-87.

Andersson, T., S. S. Serger, J. Sörvik, and E. W. Hansson. 2004. The cluster policies whitebook. Malmö, Sweden: International Organisation for Knowledge Economy and Enterprise Development. 


\section{Film and Audiovisual Production in Montreal}

Becattini, G. 1991. Italian districts: Problems and perspectives. International Studies of Management and Organization 21 (1): 83-90.

Bellet, M. 1992. Technologie et territoire, l'organisation comme objet de recherche? [Territory and technology. The organization as an object of research?] Revue française d'économie VII (1): 85-127.

Benko, G., and A. Lipietz, eds. 1992. Les régions qui gagnent, districts et réseaux: Les nouveaux paradigmes de la géographie économique. [Winning regions. Districts and regions: The new paradigms of economic geography]. Paris: PUF.

Bourdieu, P. 1980. Le capital social. Notes provisoires. [Social capital; preliminary notes]. Actes de la recherche en sciences sociales 31:8-19.

Britton, J., D. G. Tremblay, and R. Smith. 2009. Contrasts in clustering: The example of Canadian new media. European Planning Studies 17 (2): 211-35.

Britton, J., and G. Légaré. 2004. Clustered beginnings: Anatomy of multimedia in Toronto. In Clusters in a cold climate: Innovation dynamics in a diverse economy, ed. D. Wolfe and M. Lucas, 139-64. Kingston: Queen's School of Policy Studies and McGill-Queen's Univ. Press.

Brusco, S. 1994. La leçon des districts et la nouvelle politique industrielle des régions. [Lessons from the districts and the new industrial policy of regions]. In PME et développement économique en Europe, ed. A. Bagnasco and C. F. Sabel, 69-86. Paris: La Découverte, 1994.

Bureau du cinéma et de la télévision du Québec. 2007. Le bulletin d'information du bureau du cinéma et de la télévision du Québec. Montreal: BCTQ.

Camagni, R., and D. Maillat. 2006. Milieux innovateurs. Théories et politiques. [Innovative milieux. Theories and policies]. Paris: Economica.

Cassidy, E., C. Davis, D. Arthurs, and D. Wolfe. 2005. Beyond cluster-current practices and future strategies. Paper presented at the Center for Research on Industrial Clusters (CRIC) conference, Ballarat, Australia, June 30-July 1.

Cluster Network. 2007. Europe meets America. Cluster Network conference, Montreal, September 20.

Colletis, G., and B. Pecqueur. 1993. Intégration des espaces et quasi intégration des firmes: Vers de nouvelles rencontres productives? [Integration of space and quasi-integration of firms; Towards new productive encounters?] Revue d'économie régionale et urbaine 3:489-508.

Colletis, G., and F. Winterhalter. 1991. Coopération internes et externes des nouveaux districts technologiques. [Internal and external cooperations of new technological districts]. Montreal, Colloque de l'Association des sciences régionales de langue française, 23.

Courlet, C. 1994. Les systèmes productifs localisés, de quoi parle-t-on? In Industrie, territoire et politiques publiques, ed. C. Courlet and B. Soula.ge, 13-32. Paris: L'Harmattan.

Dosi, G. 1988. The nature of the innovative process. In Technical change and economic theory, eds. G. Dosi, C. Freeman, G. Silverberg, and L. Soete, 221-238. New York: Pinter.

Dosi, G., T. J. Teece, and S. G. Winter. 1990. Les frontières des entreprises: vers une théorie de la cohérence de la grande entreprise [The Frontiers of firms: Towards a theory of coherence of the large firm]. Revue d'économie industrielle, $\mathrm{1}^{\mathrm{er}}$ trimestre, 238-254.

Dupuy, C., and J. P. Gilly. 1996. Collective learning and territorial dynamics: A new approach to the relations between industrial groups and territories. Environment and Planning 28(9): 1603-1616.

E\&B DATA. 2004. Une filière d'envergure. La production audiovisuelle et les industries connexes dans la région de Montréal et au Québec. [An important sector: Audiovisual production and connected industries in the Montréal region and in Québec]. Montréal: E\&B DATA.

Ferriani, S., R. Corrado, and C. Boschetti. 2005. Organizational learning under organizational impermaneance: Collaboration ties in film project firms. Journal of Management and Governance 9: 257-85.

Fontan, J.-M., J.-L. Klein, and D.-G. Tremblay. 2004. Innovation et société: pour élargir l'analyse des effets territoriaux de l'innovation [Innovation and society: Going beyond the analysis of the territorial effects of innovation]. Géographie, économie et société 6(2): 115-128.

Fontan, J. M., J. L. Klein, and D. G. Tremblay. 2005a. Collective action in local development: The case of Angus technopole in Montreal. Canadian Journal of Urban Research 13 (2): $317-$ 36. 
Fontan, J. M., J. L. Klein, and D. G. Tremblay. 2005b. Innovation sociale et reconversion économique. Le cas de Montréal. [Social innovation and economic reconversion. The case of Montréal.] Paris: Harmattan.

Friedman, D. 1995. Why every business will be like show business, in "Inc", "Inc.com", March 1, 1995.

Garofoli, G. 1985. Industrialisation diffuse en petite entreprise: Le modèle italien des années 70. Cahiers IREP Développement 9:245-56.

Gertler, M., and D. Wolfe. 2005. Spaces of knowledge flows: Clusters in a global context. Paper presented at the Danish Research Unit on Industrial Dynamics (DRUID) tenth anniversary summer organizations conference, Copenhagen, June 27-29.

Grossetti, M., and M. P. Bès. 2001. Encastrements et découplages dans les relations scienceindustrie. [Embeddedness and decoupling in science-industry relations]. Revue française de sociologie 42 (2): $327-55$.

Haas, S. 1995. Economies externes technologiques, apprentisssage et rendement d'agglomération. In Coordination économique et apprentissage des firmes [Technological external economies, learning and agglomeration returns], ed. N. Lazaric and J. M. Mouvier, 180-225. Paris: Economica.

Hanifan, Lyda Judson. 1919. New School Code Commission Commission Report. Presented to the West Virginia Legislature. Charleston, West Virginia.

Holbrook, A., and D. Wolfe, eds. 2002. Knowledge clusters and regional innovation: Economic development in Canada. Kingston, ON: Queen's School of Policy Studies and McGill-Queen's Univ. Press.

Innovation Systems Research Network (ISRN). http://www.utoronto.ca/isrn/

Jacob, R., P. A. Julien, and L. Raymond. 1997. Compétitivité, savoirs stratégiques et innovation; les leviers de l'apprentissage collectif en contexte de réseau [Competitiveness, strategic knowledge and innovation; collective learning in a network context]. Gestion 22 (3): 93-100.

Jacobs, Jane. 1969. The Economy of Cities. New York: Random House.

Julien, P. A. 2005. Entrepreneuriat régional et économie de la connaissance. Une métaphore des romans policiers. [Regional entrepreneurship and the knowledge economy. A metaphor based on police novels]. Québec: Presses de l'université du Québec.

Julien, P.-A. and Marchesnay. L'entrepreneuriat [Entrepreneurship]. Paris: Economica.

Kirat, T. 1993. Innovation technologique et apprentissage institutionnel: Institutions et proximité dans la dynamique des systèmes d'innovation territorialisés [Technological innovation and institutional learning; Institutions and proximity in the dynamics of territorialized innovation systems]. Revue d'économie régionale et urbaine 3:547-63.

Kirat, T., and Y. Lung. 1995. Innovations et proximités: Le territoire, lieu de déploiement des processus d'apprentissage. In Coordination économique et apprentissage des firmes [Innovations and proximities: The territory as a source of learning processes], ed. N. Lazaric and J. M. Monnier, 206-27. Paris: Economica.

Klein, J.L., C. Manzagol, D.-G. Tremblay, S. Rousseau. 2005. Les interrelations université-industrie à Montréal dans la reconversion à l'économie du savoir [The interrelations between university and industry in Montreal, in the context of the Knowledge Economy] in Globalisation, Systèmes productifs et dynamiques territoriales. [Globalization, productive systems and territorial dynamics], ed. R. Guillaume, 31-54. Paris: éditions l'Harmattan, collection Géographies en liberté.

Lecoq, B. 1993. Dynamique industrielle, histoire et localisation: Alfred Marshall revisité [Industrial dynamics, history and localization: Alfred Marshall revisited]. Revue française d'économie 8:195-233.

Lin, N. 1999. Building a network theory of social capital. Connexions 22 (1): 28-51.

Lundvall, B. A. 1988. Innovation as an interactive process; from user-producer interaction to the national system of innovation. In Technical change and economic theory, ed. G. Dosi, C. Freeman, R. Nelson, G. Silverberg, and L. Soete, 349-69. New York: Pinter

Markusen, A. 2000. Des lieux-aimants dans un espace mouvant: Une typologie des districts industriels [Attractive places in a moving space; A typology of industrial districts]. In $\mathrm{La}$ richesse des régions, ed. G. Benko and A. Lipietz, 85-119. Paris: Presses universitaires de France. 


\section{Film and Audiovisual Production in Montreal}

Marshall, A. 1889. Principles of economics. London: Royal Economic Society.

Martin, R., and P. Sunley. 2003. Deconstructing clusters: Chaotic concept or policy panacea. Journal of Economic Geography 1 (3): 3-35.

Montreal Metropolitan Community. 2008. Les grappes et l'innovation: Libérer le capital créatif [Clusters and innovation: Liberating the creative capital]. Montreal: Montreal Metropolitan Community.

National Research Council. 1998. Supporting the knowledge-based economy in the 21st century. Ottawa, ON: National Research Council.

Nelson R. R., and S. G. Winter. 1982. An evolutionary theory of economic change. Cambridge, MA: Belknap Press/Harvard University Press.

Organisation for Economic Co-operation and Development. 1999. Boosting innovation: The cluster approach. Paris: Organisation for Economic Co-operation and Development.

. 2001. Innovative clusters: Drivers of national innovation systems. Paris: Organisation for Economic Co-operation and Development.

Padmore, T., and H. Gibson.1998. Modeling systems of innovation, part II: A framework for industrial cluster analysis in regions. Research Policy 26:625-41.

Pecqueur, B. 1989. Le développement local [Local development]. Paris: Syros/Alternatives. 1996. Processus cognitifs et construction des territoires économiques [Cognitive processes and construction of economic territories]. In Dynamiques territoriales et mutations économiques, ed. B. Pecqueur., 209-26. Paris: L'Harmattan.

Piore, Michael. J., and Charles, F. Sabel. 1984. The Second Industrial Divide. New York: Basic Books.

Planque, B., and B. Py. 1986. La dynamique de l'intégration des PME innovatrices dans leur environnement: Problématique et propositions méthodologiques [The dynamics of integration of innovative SMBs in their environment; problematics and methodological propositions]. Revue d'économie régionale et urbaine 5:587-607.

Porter, M. E. 1990. The competitive advantage of nations. New York: Free Press.

2003. The economic performance of regions. Regional Studies 37(6-7): 549-78.

2005. Local clusters in a global economy. In Creative industries, ed. J. Hartley., 259-67. Malden, MA: Blackwell.

Rifkin, J. 2005. When markets give way to networks... everything is a service. In Creative industries, ed. J. Hartley., 361-74. Malden, MA: Blackwell.

Salais, R., and M. Storper. 1993. Les mondes de production [The worlds of production]. Paris: Editions de l'école des hautes etudes en sciences sociales.

Salvemini, S., and G. Delmestri. 2000. Governance in the movie industry: Alternatives to Hollywood? International Journal of Arts Management 2 (2): 59-73.

Scott, A. 1999. Les bases géographiques de la performance industrielle [The geographic bases of industrial performance]. Géographie, Économie, Société 1 (2): 259-80.

Smith, R., J. McCarthy, and M. Petrusevich. 2004. Clusters or whirlwinds? The new media industry in Vancouver. In Clusters in a cold climate: Innovation dynamics in a diverse economy, ed. D. Wolfe and M. Lucas, 195-221. Kingston, ON: Queen's School of Policy Studies and McGillQueen's Univ. Press.

Starkey, K., C. Barnatt and S. Tempest. 2000. Beyond Networks and Hierarchies; Latent organizations in the UK television industry. In How organizations learn: Managing the search for knowledge, 259-270. New York: Thomson.

Statistics Canada. 2003/2005. Survey of Innovation Questionnaire. Ottawa: Statistics Canada.

Storper, M. 1997. Les nouveaux dynamismes régionaux: Conventions et systèmes d'acteurs [The new regional dynamisms; conventions and actors systems]. In Action collective et décentralisation, ed. S. Coté, J. L. Klein, and M. U. Proulx, 1-17. Rimouski, QC: GRIDEQ.

Tremblay, Diane-Gabrielle and Jean-Marc Fontan. 1994. Le développement économique local; la théorie, les pratique, les expériences [Local economic development: Theory, practice and initiatives]. Québec: Presses de l’Université du Québec.

Tremblay, D. G. 2003. New types of careers in the knowledge economy? Networks and boundaryless jobs as a career strategy in the ICT and multimedia sector. In Communications and strategies, 81-106. Montpellier, France: IDATE. 
Tremblay, D. G., C. Chevrier, and S. Rousseau. 2004. The Montreal multimedia sector: District, cluster or localized system of production? In Clusters in a cold climate: Innovation dynamics in a diverse economy, ed. D. Wolfe and M. Lucas, 165-194. Montreal: McGill-Queen's Univ. Press.

Tremblay, D. G., J. M. Fontan, J. L. Klein, and D. Bordeleau. 2002. The development of the relational firm: The case of the multimedia city in Montréal. In Knowledge, clusters and regional innovation: Economic development in Canada, ed. A. Holbrook and D. Wolfe, 161-85. Toronto: McGill-Queens Univ. Press.

Tremblay, D. G., and S. Rousseau. 2005. Le secteur du multimédia à Montréal peut-il être considéré comme un milieu innovateur? [Can the Montreéal Multimedia sector be considered as an innovative milieu?] In Géographie, economie et société, Paris: Lavoisier.

Veltz, P. 1996. Mondialisation, villes et territoires. L'economie d'archipel [Globalization, cities and territories. The Archipel Economy]. coll. Economie en liberté. Paris: Presses universitaires de France.

Wolfe, D., C. Davis, and M. Lucas. 2005. Global networks and local linkages: An introduction. In Global networks and local linkages, 1-23. Montreal: McGill-Queen's Univ. Press. 